\title{
Life cycles in brackish habitats: adaptive strategies of some polychaetes from the Venice lagoon
}

\section{Cycles vitaux dans des habitats saumâtres : stratégies adaptatives de quelques polychètes dans la lagune de Venise}

\author{
Daniela Prevedelli *, Roberto Simonini \\ Dipartimento di Biologia Animale, Università degli Studi di Modena e Reggio Emilia, Via Campi 213D, 41100 Modena, Italy
}

Received 31 July 2002; accepted 30 September 2002

\begin{abstract}
The life cycle of five species of polychaetes living in the Venice lagoon is analysed with the aim of finding out if some traits can be interpreted as an adaptation to brackish environments. The studied species are characterized by different sizes and reproductive strategies. Marphysa sanguinea is a large-sized, annual iteroparous species belonging to the Eunicidae family that reproduces without epitokal modification. Perinereis cultrifera and P. rullieri are large-sized semelparous species belonging to the Nereididae family: the first reproduce with epitokal metamorphosis, the second do not. Ophryotrocha labronica and Dinophilus gyrociliatus are small iteroparous species with semi-continuous reproduction belonging to the Dorvilleidae and Dinophilidae families, respectively. All the species are gonochoric. The larger species often have a sex ratio close to 1:1, while in the smaller ones the sex ratio is biased toward the female sex (2:1 in $O$. labronica and 3:1 in D. gyrociliatus). Moreover, D. gyrociliatus exhibits strong sexual dimorphism: the males are dwarf and short living. All the large-sized species have external fertilization, while the small-sized $O$. labronica and $D$. gyrociliatus exhibit external fertilization with pseudo-copulation and internal fertilization, respectively, that ensure a high reproductive success. All the species produce lecitotrophic eggs, protect young stages from at least some environmental stresses and reduce larval dispersion. The role of the suppression of epitoky and protection structure for developing eggs in limiting the dispersal phase is discussed. All species, independent of reproductive strategies, are characterized by high fecundity and reproductive effort. In the small-sized species, the marked bias of the sex ratio in favour of the female sex and, in D. gyrociliatus, the reduction in the size of the male eggs, are significant factors in the increasing rate of the populations, enabling them to tolerate sharp variation in density due to environmental unpredictability.
\end{abstract}

(C) 2003 Éditions scientifiques et médicales Elsevier SAS and Ifremer/CNRS/IRD. All rights reserved.

\section{Résumé}

Le cycle de vie de cinq espèces de polychètes de la lagune de Venise est étudié de manière à analyser d'éventuelles adaptations au milieu saumâtre. Les espèces prises en compte sont caractérisées par des tailles et des stratégies de reproduction différentes. Marphysa sanguinea est une espèce de grande taille, itéropare annuelle, appartenant à la famille des Eunicidae qui se reproduit sans modification de l'épitoque. Perinereis cultrifera et $P$. rullieri, également de grande taille, sont des espèces hémipares appartenant aux Nereididae : la première se reproduit avec métamorphose de l'épitoque, la seconde sans métamorphose. Ophryotrocha labronica et Dinophilus gyrociliatus, qui appartiennent respectivement aux familles des Dorvilleidae et des Dinophilidae, sont de petites espèces itéropares avec une reproduction semi-continue. Toutes ces espèces sont gonochoriques. Les espèces les plus grandes présentent un sex-ratio voisin de 1:1 alors que, chez les plus petites, ce taux est biaisé vers le sexe femelle (2:1 chez $O$. labronica et 3:1 chez D. gyrociliatus). De plus, D. gyrociliatus présente un dimorphisme sexuel marqué avec des mâles nains à vie brève. Toutes les espèces de grande taille présentent une fécondation externe alors que celles de petite taille, $O$. labronica et $D$. gyrociliatus, présentent respectivement une fécondation externe avec pseudo-copulation et une fécondation interne, ce qui garantit un taux de reproduction élevé. Toutes les espèces élaborent des œufs riches en lécithine, protègent les juvéniles de certains stress environnementaux et réduisent la dispersion larvaire. Le rôle de la suppression de l'épitoquie et des structures de protection de l'œuf en limitant la dispersion est discuté. Toutes les espèces présentent une fécondité élevée et un effort de reproduction. Chez les espèces de petite

* Corresponding author.

E-mail address: prevedelli.daniela@unimore.it (D. Prevedelli). 
taille, le sex-ratio favorable aux femelles et, chez D. gyrociliatus, la réduction de taille des œufs mâles, favorisent l'accroissement des populations leur permettant de tolérer les variations brusques de densité dans un environnement éminemment variable.

(c) 2003 Éditions scientifiques et médicales Elsevier SAS and Ifremer/CNRS/IRD. Tous droits réservés.

Keywords: Life cycle; Brackish water; Reproductive strategies; Polychaeta; Venice lagoon

Mots clés : Cycles vitaux ; Eaux saumâtres ; Stratégies de reproduction ; Polychètes ; Lagune de Venise

\section{Introduction}

All traits of the life history are often closely related and are a result of interactions between phylogenetic, physiological and morphological constraints and the processes by which the organisms adapt to the environment in which they live and reproduce. Among morphological constraints, body size is of paramount importance. Moreover, the characteristics of the life history and the modality of dispersion determine how a species responds to perturbation and stress (Stearns, 1976; Levin, 1984; Olive, 1984; Sibly and Calow, 1989; Giangrande, 1997; Brommer, 2000; Prevedelli and Simonini, 2002).

Polychaetes are among the marine organisms that have had the greatest evolutionary success. They are very abundant and widely distributed, both ecologically and geographically, in marine environments, while a significant component has also colonized brackish habitats. Being one of the groups best represented in unpredictable environments, they have been widely studied in an attempt to understand what characteristics of their life cycle and life history have enabled them to colonize and survive in such habitats (Grassle and Grassle, 1974; Mettam, 1980; Eckelbarger, 1983; Fauchald, 1983; Levin, 1984; Wilson, 1991; Bhaud and Duchêne, 1996; Hadfield and Strathmann, 1996; Giangrande, 1997). In many species of polychaetes living in coastal environments, systems for the protection of the eggs and embryos are present, while species living in the open sea can spawn freely in the external environment where fertilization and development occur. The forms of protection are strictly related to different types of development and in most cases the forms of protection are present in species with a direct development, whilst the species that release their gametes directly by external means have a pelagic development (Thorson, 1950; Giangrande, 1997).

Variations of some traits of the life cycle in relation to the characteristics of brackish environments have mainly been studied in polychaetes belonging to the family Nereididae (Mettam, 1980); they concern mainly the patterns of reproduction and generally lead to the suppression of the epitoky, to the shift of the sex ratio towards the female sex and to the reduction or disappearance of the dispersal phase. The Nereididae, however, are typically semelparous and die after reproduction, but different species of polychaetes that live in brackish waters are iteroparous and survive after reproduction. Among the iteroparous organisms, there are the annual species, which reproduce at intervals of 1 year and are gen- erally large-sized, and the continuous or semi-continuous species, which, once they have reached maturity, reproduce continuously or at short intervals of time during a more or less extended reproductive season and are generally smallsized.

In this paper, we analyse some aspects of the life cycle of five species of polychaetes, with different reproductive strategies and different body sizes, collected from the Venice lagoon with a view to identify those characteristics that can be related to their colonization of the brackish environment. In particular, we take into account (i) the way in which gametes are released, fertilization and the presence of systems for the protection of eggs and embryos, (ii) larval development patterns and (iii) allocation of resources to reproduction. The species that have been taken into account are Marphysa sanguinea Montagu (Eunicidae), Perinereis cultrifera Grube (Nereididae), Perinereis rullieri Pilato (Nereididae), Ophryotrocha labronica La Greca and Bacci (Dorvilleidae) and Dinophilus gyrociliatus O. Schmidt (Dinophilidae).

\section{Materials and methods}

\subsection{Collection methods}

All the five species were obtained from the Venice lagoon. The collection sites are shown in Fig. 1. M. sanguinea and $P$. cultrifera were collected in the "Valle della Dolce" southwest of Chioggia. Sampling took place at low tide; the individuals were extracted from the sediment by hand, care being taken not to damage them. Specimens of $P$. rullieri were manually collected at low tide from underneath the stones where they lived. $M$. sanguinea, $P$. cultrifera and $P$. rullieri were collected every month throughout the annual cycle starting from April 1993.

$O$. labronica and $D$. gyrociliatus were obtained by scraping the wharves of harbours and lagoons with a sharp-edged net with a handle. In the laboratory, the samples were transferred to small aquariums kept at $20-24{ }^{\circ} \mathrm{C}$. After a few hours, conditions at the bottom of the tanks became anoxic, causing many of the animals to climb up the walls to reach the surface, whence, after identification, they can be removed with a pipette. For each species, more than 100 specimens were considered, representative of the whole populations. The energy content of germinal and somatic tissues was determined by differential scanning calorimeter (DSC). The reproductive effort was calculated with the formula 


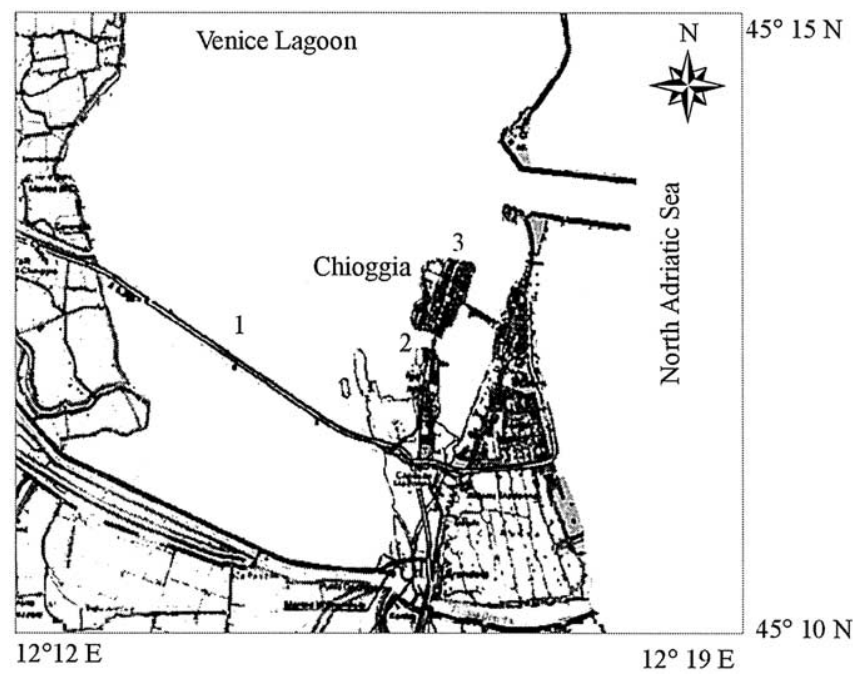

Fig. 1. Collecting site of the studied species: (1) Marphysa sanguinea and Perinereis cultrifera; (2) P. rullieri; (3) Dinophilus gyrociliatus and Ophryotrocha labronica.

$\mathrm{RE}=E_{\mathrm{G}} /\left(E_{\mathrm{G}}+E_{\mathrm{S}}\right)$ for semelparous and semi-continuous species. For $M$. sanguinea, the reproductive effort was calculated per unit time as $\delta E_{\mathrm{G}} /\left(\delta E_{\mathrm{G}}+\delta E_{\mathrm{S}}\right)$ (Grémare and Olive, 1986; Cassai and Prevedelli, 1998a, b, 1999).

\subsection{Characteristics of the species studied}

The life cycle of the large species (M. sanguinea, $P$. cultrifera, $P$. rullieri) was studied both in the field and in the laboratory, while that of the two small species (O. labronica and $D$. gyrociliatus) was studied exclusively in the laboratory. The life cycle and reproductive characteristics of $M$. sanguinea, $P$. cultrifera and $P$. rullieri are reported in Cassai and Prevedelli (1998a, b) and Prevedelli and Cassai (2001). The principal characteristics of the species considered are summed up in Table 1

\subsection{Marphysa sanguinea Montagu, 1815 (Eunicidae)}

M. sanguinea is a species typical of muddy bottoms. It is a polychaete of considerable size, attaining a maximum length of about $40 \mathrm{~cm}$. It is a gonochoric species, with an annual iteroparous reproductive strategy, that lives in burrows in the sediment at a depth of $25-35 \mathrm{~cm}$. The studied population in the Venice lagoon reproduces in March and the sex ratio is 1:1 (female:male). There are no morphological differences between the males and the females; however, the latter can be distinguished for a part of the year by the presence of oocytes visible through the body wall in the coelomic cavities. The gonads are present in all the abdominal segments, which start from the 60th setigerous segment; the first 60 segments are characterized by a very robust musculature, but there are no sites of gametogenic activity as there are in the last 50 segments, which revert to being sterile. The gonads are discrete organs present in all the fertile segments. Epitokous metamorphosis has never been observed in this species (Prevedelli, 1989).

\subsection{Perinereis rullieri Pilato, 1974 (Nereididae)}

Perinereis rullieri belongs to the Nereididae family and, in the Venice lagoon, lives inside burrows dug in the fine grain sediment. This species, at our current state of knowledge, is endemic to the Mediterranean Sea. In the Venice lagoon, it attains very high densities. It is a gonochoric species with a semelparous strategy; the males and females are distinguishable only when they are sexually mature, the females become greenish in colour while the males assume a milky appearance. The sex ratio is about $1: 1$, even though in the course of a year's sampling, it may vary considerably. In the Venice lagoon, the individuals attain a maximum length of about $20 \mathrm{~cm}$, and reproduces between March and April. In no cases have epitokal modifications been observed (Prevedelli et al., 1990; Prevedelli and Cassai, 2001).

Table 1

Morphological and reproductive characteristics of the studied species from the Venice lagoon. References: 1: Cassai and Prevedelli (1998a); 2: Cassai and Prevedelli (1998b); 3: Prevedelli and Cassai (2001); 4: original data

\begin{tabular}{|c|c|c|c|c|c|}
\hline & M. sanguinea $a^{1,4}$ & P. rullieri ${ }^{2}$ & P. cultrifera ${ }^{3}$ & O. labronica ${ }^{4}$ & D. gyrociliatus $^{4}$ \\
\hline Body length (mm) & $100-450$ & $50-149$ & $48-110$ & $3.0-3.5$ & $0.8-1.2$ \\
\hline Reproductive strategy & Iteroparous & Semelparous & Semelparous & $\begin{array}{l}\text { Iteroparous } \\
\text { (semi-continuous) }\end{array}$ & $\begin{array}{l}\text { Iteroparous } \\
\text { (semi-continuous) }\end{array}$ \\
\hline Epitoky & No & No & Yes & No & No \\
\hline Fertilization & External & External & External & External & Internal \\
\hline Egg size $(\mu \mathrm{m})$ & $300-320$ & 370 & 300 & 120 & 100 \\
\hline Fecundity (eggs/female) & $8500-24300$ & $6300-15000$ & $7700-26000$ & $94-1484$ & $10-150$ \\
\hline Protective structure & $\begin{array}{l}\text { Eggs laid in the } \\
\text { maternal tube }\end{array}$ & Jelly matrix & Jelly matrix & Gelatinous tubes & Capsule \\
\hline $\begin{array}{l}\text { Development mode; first } \\
\text { free-living stage }\end{array}$ & Indirect; trochofora & Indirect; nectochaeta & Indirect; nectochaeta & Direct; juvenile & Direct; juvenile \\
\hline $\begin{array}{l}\text { Length of the first } \\
\text { free-living stage }(\mu \mathrm{m})\end{array}$ & $300-320$ & 400 & 350 & 200 & 150 \\
\hline Sex ratio & $1 \%: 1 \delta^{\hbar}$ & $1 \%: 10$ & $1+1$ ठै & $2 \%: 10$ & $3 \%: 10$ \\
\hline Reproductive effort & $0.120(0.04-0.190)$ & $0.62(0.34-0.83)$ & $0.79(0.53-0.90)$ & $0.84(0.60-0.96)$ & $0.90(0.58-0.95)$ \\
\hline
\end{tabular}

Prevedelli D., Simonini R. 


\subsection{Perinereis cultrifera Grube, 1840 (Nereididae)}

In the Venice lagoon, Perinereis cultrifera lives in a layer of sandy silt extending to a depth of about $15 \mathrm{~cm}$ in the same area colonized by $M$. sanguinea. Similar to its congeneric $P$. rullieri, it is a gonochoric species with a semelparous strategy and a sex ratio close to $1: 1$. Unlike $P$. rullieri, in the Venice lagoon, the individuals attain a maximum length of $11 \mathrm{~cm}$ and reproduce in March. This species has retained epitokous metamorphosis in its life cycle.

\subsection{Ophryotrocha labronica La Greca and Bacci, 1962 (Dorvilleidae)}

$O$. labronica is a small-sized polychaete $(3-3.5 \mathrm{~mm}$ in length) that typically lives in the fouling community of polluted harbours, also found recently in brackish habitats ( $\mathrm{Si}$ monini, 2002). This species exhibits an iteroparous semicontinuous reproductive strategy. $O$. labronica was originally described as a protandric hermaphroditic species (La Greca and Bacci, 1962). The population living in the Venice lagoon, as indeed other populations hitherto studied, is gonochoric with the sex ratio biased in favour of the females in the ratio 2:1 (Lanfranco and Rolando, 1981). There is an apparent sexual dimorphism between males and females in the jaws, and in mature females, the oocytes are visible through body walls (Åkesson, 1973).

\subsection{Dinophilus gyrociliatus $O$. Schmidt, 1857 (Dinophilidae)}

D. gyrociliatus is a cosmopolitan interstitial polychaete that, as $O$. labronica, colonizes both harbours and brackish habitats (Prevedelli and Simonini, unpublished data). This species exhibits a marked sexual dimorphism that is already evident at the zygote stage: the adult females $(0.8-1.2 \mathrm{~mm}$ in length) lay transparent ovigerous capsules containing small "male-type" eggs (ME), $40 \mu \mathrm{m}$ in diameter, from which males usually originate, and large "female-type" eggs (FE), 80-100 $\mu \mathrm{m}$ in diameter, which normally develop into females. At $24^{\circ} \mathrm{C}, 5$ or $6 \mathrm{~d}$ after spawning, the young fertilized females emerge from the capsules to give rise to the freeliving population. The sex ratio is biased to the female sex in the ratio of about 3:1, but it may be influenced by genetic, environmental and also maternal factors (Malsen, 1906; Tzonis, 1938; Traut, 1969; Prevedelli and Zunarelli Vandini, 1999; Prevedelli and Simonini, 2000).

\section{Results and discussion}

\subsection{Emission of gametes, fertilization and protection of the eggs}

The species studied display important differences in the patterns of gamete emission and fertilization Table 1. In $M$. sanguinea, fertilization is external, but the males and females are close at the moment of spawning; in fact, the sperms in this species are neither very numerous nor very mobile, having a very short tail. $M$. sanguinea lays the eggs inside the burrows where the adults live; there are no protective structures, the protection of the eggs being ensured by the burrow itself. In $P$. rullieri and $P$. cultrifera, fertilization takes place externally and the gametes are released following lysis of the body wall. Both species are semelparous and die after reproduction, but there is an important difference in their life cycle: the former species reproduces in the atokous stage, while the latter retains the epitokal modification. In both the species, the newly fertilized eggs tend to agglutinate to form large clusters that, in the laboratory, adhere to the walls of the aquarium, while in their natural environment, they attach themselves to stones or suitable substrates. In the case of $P$. cultrifera, which lives in an open area of the lagoon, the egg clusters often adhere to the shells of large molluscs. In $O$. labronica, fertilization is external but a sort of pseudo-copulation takes place; the male is on the back of the female at the moment of spawning and fertilizes the eggs as the female lays them. The eggs are protected by a thick, elastic jelly matrix and the parents also play their part: the females remain close to the egg clusters and, with their body movement, ensure oxygenation and make it more difficult for parasites to attack them. In D. gyrociliatus, both the male and the female eggs are laid inside a very strong gelatinous capsule that adheres to the substrate. Fertilization takes place internally, with the small simplified males fertilizing their sisters inside the same ovigerous capsule.

All the species studied produce lecitotrophic eggs ranging in size from $370 \mu \mathrm{m}$, in the case of $P$. rullieri, to $100 \mu \mathrm{m}$, in the case of the female eggs of D. gyrociliatus Table 1). Egg size is an important life history trait, being an indicator of energy investment per offspring. Large eggs rich in food reserves allow lecitotrophic or direct development, thus avoiding the particularly high risks associated with planktotrophy in brackish environments. Small-sized species cannot generate enough energy and do not have enough space to produce a large number of eggs in a single episode; hence they typically produce a small number of large eggs often associated with protective systems (Westheide, 1984; Giangrande, 1997). In D. gyrociliatus, the size of the two types of eggs also plays a crucial role (much more important than the sex ratio) in determining the quantity of resources to be allocated to the males: accordingly, only $4-5 \%$ is invested in the male function (Charnov, 1987).

In $M$. sanguinea and $P$. rullieri, spawning takes place without the individuals modifying their structure; in no case have individuals been observed that present epitokous modifications even if epitoky is the norm for marine Eunicidae and Nereididae (Hofmann, 1972, 1974, 1975; Smith, 1958). The disappearance of the epitokous stage in the species that colonize brackish environments seems to be a general phenomenon that is particularly evident in Nereididae probably on account of their massive presence in such habitats. Smith (1958) suggested that the epitokous stage with free spawning and planktonic larvae is the primitive reproductive form in Nereididae; those species living in brackish environments tend to avoid free spawning, leading to atokous reproduction. 
In fact, the suppression of epitoky is a common trend in estuarial species (Mettam, 1980; Olive et al., 1984; Prevedelli and Cassai, 2001). Moreover, this characteristic is quite probably related to a reduction in the dispersal phase (Giangrande, 1997).

It should be noted that in all the species, regardless of their reproductive strategy, systems of varying degrees of complexity are in place for the protection of the eggs Table 1. The simplest system is undoubtedly that adopted by M. sanguinea, which also conserves in its life cycle a pelagic phase, albeit much reduced. All the other species, however, protect their eggs in a jelly matrix. Species producing large eggs often encapsulate them in a jelly matrix, which is probably an efficient system of risk-avoidance. The jelly matrix has been attributed with various functions, such as promoting successful fertilization (Sato and Osanai, 1996), protecting the embryos during early development (Vance, 1973; Schroeder and Hermans, 1975), supplying food for the developing embryos (Bookhout and Horn, 1949; Sato et al., 1982) and limiting the dispersal of the juveniles to keep them in a suitable habitat (Chapman, 1965; Gibbs, 1968; Sato et al., 1982; Nishihira et al., 1984). Strathman (1980, 1982) suggests that the presence of a jelly matrix may be an adaptation to the local condition and that the estuarial and insular populations tend to keep the eggs. For those species inhabiting an environment characterized by very peculiar ecological features, the reduction of dispersal is a prerequisite for the maintenance of populations (Bhaud and Duchêne, 1996). The high frequency with which species inhabiting such environments spawn mucilaginous structures supports the hypothesis that they need to control dispersal in unstable environments. This is true for Scoloplos armiger and Eupolymnia nebulosa. In fact, Gibbs (1968) retains that the most important function of the cocoon in Scoloplos is to prevent the wide dispersal of the larvae, and Bhaud and Duchêne (1996) report that in Eupolymnia nebulosa, the salinity inside the mucilaginous egg masses follows external conditions and suggest that egg masses are more a protection against dispersal than against predation or variation of osmolarity. The need to reduce dispersion does not, however, seem to be exclusive to estuarial species; some species of Nereididae that live in the open sea encapsulate their eggs in gelatinous matrices, hatching taking place at the nectochaete stage, even though they often conserve the epitokous modification in their life cycle. This has been observed in a Pacific population of Perinereis nuntia var. brevicirrus (Hardege and Bartels-Hardege, 1995). All these observations suggest that the gelatinous egg mass in which larvae undergo direct development is a response to the constraint of dispersal. The role of the gelatinous mass is particularly important in the case of small-sized species whose population density in these habitats is often low. In D. gyrociliatus, in particular, it is not only larval development but also fertilization that take place in the capsule. Westheide (1984) and Sella and Ramella (1999) have suggested that the particular reproductive mechanism of $D$. gyrociliatus may be an adaptation to low population density, in which the meeting of two individuals of different sex is most unlikely. D. gyrociliatus is believed to have overcome the problem of finding partners by means of the progenetic development of males that couple with the immature females inside the ovigerous capsule. This characteristic, which has evolved in response to the selective pressures of the interstitial environments, could account for its success in colonizing typically unpredictable habitats.

\subsection{Larval development}

The schematic representation of the life cycle of the species studied is given in Fig. 2 None of the species studied exhibits pelagic stages in their life cycles, with the exception of $M$. sanguinea whose pelagic stage is anyway reduced to just a few hours. In this species, in fact, the trochophore is driven by a strong positive phototrophism to leave their parents' burrow and seek the surface of the water, where they complete their larval development. Development up to the nectochaete with four setigerous segments proceeds using the yolk contained in the egg as a food resource; indeed, only when four segments have developed is the masticator apparatus perfectly formed and fully functional and the intestine canalized. Up to this stage, the larvae produce a sticky substance that anchors them to the substrate and prevents them from being swept in the open sea by the action of the tide. From this stage onwards, their greater mobility enables them to incorporate particles of sediment into the mucilaginous substance, and they begin to build themselves a tube inside which they live. According to Cazaux (1981), larval development in nereidids presents four stages: trochophore I, trochophore II, metatrochophore I and metatrochophore II. In $P$. cultrifera and $P$. rullieri, the larval stages of trochophore and metatrochophore are completed inside the gelatinous egg mass, and the first free-living stage is the nectochaete that has already acquired benthic habits.

Neither in O. labronica nor in D. gyrociliatus is there an evident dispersal phase. In both species, development is direct: from the egg emerges an individual small in size but with the same morphological characteristics as those of the adult. The reduction, or actual disappearance, of the pelagic stage in the larval development of the species that have colonized the brackish environments seems to be extremely common. Bhaud and Duchêne (1996) maintain that, for those species that live in habitats characterized by instability of the ecological conditions, reduced dispersion is crucial to the maintenance of the population. Most probably, it is also one of the fundamental characteristics that has enabled $O$. labronica and D. gyrociliatus to colonize brackish environments. In the other species studied, the reduction in dispersion leads to an early acquisition of benthic habits, which, in the case of $M$. sanguinea, results in the construction of a mucous tube inside which the larva lives, while in other species, it is achieved with the encapsulation of the typically pelagic stages in the protective structures. 


\section{M. sanguinea
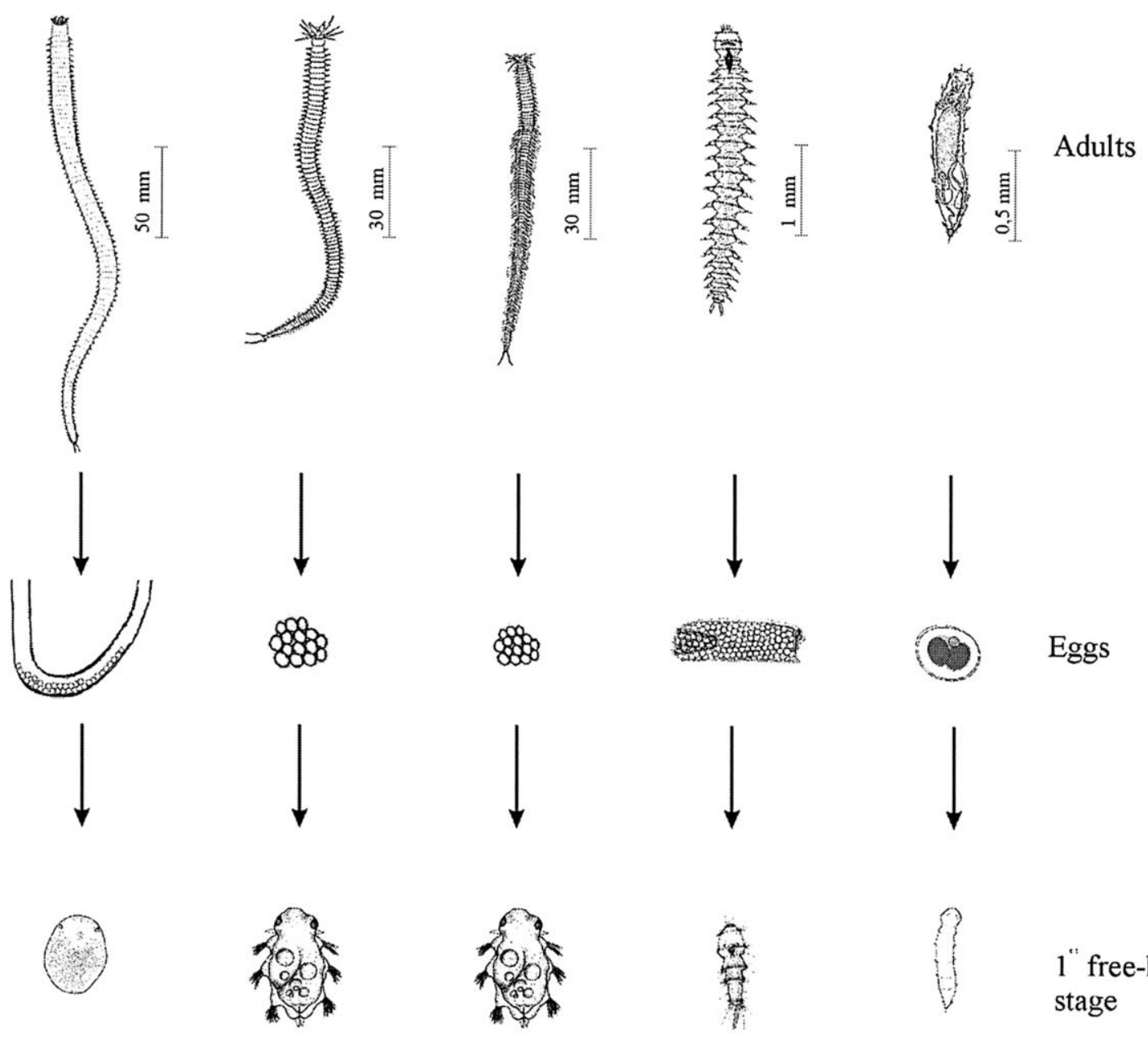

$1 "$ free-living

Troc.

Nect.

Nect.

Juv.

Juv.

Fig. 2. Schematic representation of reproductive and developmental characteristics of the studied species. Adult specimens, eggs and free-living stage are not at the same scale (for size, see Table 1). Troc $=$ trochophora; Nect $=$ nectochaeta; Juv = juvenile.

\subsection{Differentiation of age at reproduction in the semelparous species}

In the semelparous species, $P$. rullieri and $P$. cultrifera, there is another very important characteristic that can be connected with the colonization of brackish environments: in these species, not all the individuals reproduce at the same age (Cassai and Prevedelli, 1998a). The more precocious individuals reproduce at 1 year while others delay reproduction until the second or third year of life. Different ages at maturity have also been observed for Nereis diversicolor and N. pelagica (Olive and Garwood, 1981). Differentiation of age at reproduction ensures that adult worms are always present in the population. This may be an important adaptation for species that live in brackish habitats characterized by environmental instability. This shift in reproductive age has also been observed in other nereidids living in estuarial habitats (Brafield and Chapman, 1967; Olive and Garwood, 1981).

\subsection{Allocation of resources to reproduction}

All the species studied produce large lecitotrophic eggs. The allocation of resources to reproduction was studied and, in the case of $M$. sanguinea, $P$. rullieri, $P$. cultrifera and $O$. labronica, the reproductive effort was calculated in terms of the energy content of the somatic and germinal tissues. In D. gyrociliatus, the reproductive effort was calculated based on the assumption that the quantity of energy $(\mathrm{J} / \mathrm{g})$ contained in the soma and in the gametes is equal to that of $O$. labronica. The percentage of energy allocated to reproduction in the species studied is reported in Table 1 Further details regarding methods are reported in Cassai and Prevedelli (1998a, b, 1999).

In $M$. sanguinea, the average value of reproductive effort $(12 \%)$ is not directly comparable with that of the other species since it refers to a single reproductive episode. The true reproductive effort (sensu Havenhand and Todd, 1989) is therefore greater than this and may exceed one in the longer- 
lived animals. Of the species studied, $M$. sanguinea is undoubtedly the one that invests most heavily in the soma; it attains considerable size and also displays a number of segments that are not sites of gametogenic activity. In this species, the 60 thoracic segments that are sterile and equipped with a particularly robust musculature, which enables the adults to dig the burrows in which they live, must surely reduce the reproductive effort. Data in the literature relating to energy allocation in iteroparous polychaetes are rather scanty; data are available only for Harmotoe imbricata (Grémare and Olive, 1986) and for Nephtys caeca and $N$. hombergi (Olive et al., 1997). In all the other species, reproductive effort was calculated from the data relating to the whole life cycle and can therefore be compared. It should be noted that the relative values of reproductive effort increase as the size of the species decreases, thus confirming that body size is a morphological constraint of fundamental importance in determining the characteristics of the life histories. In the two semelparous species, reproductive effort is generally high; in fact, there is no trade-off in these species between fecundity and adult survival, since the individuals die immediately after reproducing and so the bulk of the energy is allocated to reproduction. Reproductive effort is greater in $P$. cultrifera, which is smaller and conserves epitokous metamorphosis. Epitokous metamorphosis is a process that takes place through the metabolism of somatic tissues in order to change the shape of the body, so it could play a part in this difference (Cassai and Prevedelli, 1998a).

The greatest reproductive effort of all was observed in the small-sized species characterized by a semi-continuous iteroparous reproductive strategy. In these species, which cannot produce and store a number of gametes in their bodies to ensure the perpetuation of the species, not only is there a very high reproductive effort, understood as the quantity of energy allocated to reproduction, but there is also a shift of the sex ratio in favour of the female sex, so that more females are produced than males. This "saving" is extreme in D. gyrociliatus, which reduces not only the number but also the size of the males, thus economizing as much as possible. The reduced allocation in the male function, averaged with a production of a higher number of females and, above all, with a drastic reduction of the male body size, appears frequently when mating occurs among siblings, and males do not compete for females (Hamilton, 1967; Charnov, 1982, 1987).

\section{Conclusions}

It is difficult to find correlations between life history features and environmental characteristics where the species live or their geographical distribution since phylogenetic and morphological constraints condition the main traits of the polychaetes' reproductive biology (Giangrande, 1997). The species studied exhibit a wide differentiation in size and in reproductive strategies and also important differences in the ways in which gametes are released and fertilization takes place. Yet, they have many characteristics in common. The great investment in reproduction, with adaptations taken to the extreme in the small-sized species that, on account of their size, cannot invest in the number of progeny, is a characteristic that has enabled them to live in brackish environments. Moreover, all the species operate systems of protection for eggs and embryos, which also seem to play a crucial role in limiting the stage of dispersion. These life history features could have permitted these polychaetes to colonize and successfully inhabit brackish environments such as the Venice lagoon.

\section{References}

Åkesson, B., 1973. Reproduction and larval morphology of five Ophryotrocha species (Polychaeta Dorvilleidae). Zool. Scr. 2, 145-155.

Bhaud, M., Duchêne, J.C., 1996. Life cycle evolution: change from indirect to direct development as an adaptive answer to dissemination constraints? Oceanol. Acta 19 (3-4), 335-346.

Bookhout, C.G., Horn, E.C., 1949. The development of Axiothella mucosa (Andrews). J. Morph. 84, 145-184.

Brafield, A.E., Chapman, G., 1967. Gametogenesis and breeding in a natural population of Nereis virens. J. Mar. Biol. Assoc. UK 47, 619-627.

Brommer, J.E., 2000. The evolution of fitness in life-history theory. Biol. Rev. 75, 377-404.

Cassai, C., Prevedelli, D., 1998a. Reproductive effort, fecundity and energy allocation in two species of the genus Perinereis (Polychaeta: Nereididae). Invert. Reprod. Dev. 34 (2-3), 125-131.

Cassai, C., Prevedelli, D., 1998b. Reproductive effort, fecundity and energy allocation in Marphysa sanguinea (Polychaeta: Eunicidae). Invert. Reprod. Dev. 34 (2-3), 133-138.

Cassai, C., Prevedelli, D., 1999. Fecundity and reproductive effort in Ophryotrocha labronica (Polychaeta: Dorvilleidae). Mar. Biol. 133, 489-494.

Cazaux, C., 1981. Évolution et adaptation larvaires chez les polychètes. Océanis 7, 43-77.

Chapman, G., 1965. The egg cocoons of Scoloplos armiger O.F. Muller. Biol. Bull. 128, 189-197.

Charnov, E.L., 1982. The Theory of Sex Allocation. Princeton University Press, Princeton, NJ.

Charnov, E.L., 1987. Local mate competition and sex ratio in the diploid worm Dinophilus gyrociliatus. Int. J. Invert. Reprod. Develop (Amsterdam) 12, 223-225.

Eckelbarger, K.J., 1983. Evolutionary radiation in polychaetes ovaries and vitellogenic mechanisms: their possible role in life history patterns. Can. J. Zool. 61, 487-504.

Fauchald, K., 1983. Life diagram patterns in benthic polychaetes. Proc. Biol. Soc. Wash 96, 160-177.

Giangrande, A., 1997. Polychaete reproductive patterns, life cycles and life histories: an overview. Oceanogr. Mar. Biol. Ann. Rev. 35, 323-386.

Gibbs, P.E., 1968. Observation on the population of Scoloplos armiger at Whitstable. J. Mar. Biol. Assoc. UK 48, 225-254.

Grassle, J.F., Grassle, J.P., 1974. Opportunistic life histories and genetic systems in marine benthic polychaetes. J. Mar. Res. 32, 253-284.

Grémare, A., Olive, P.J.W., 1986. A preliminary study of fecundity and reproductive effort in two polychaetous annelids with contrasting reproductive strategies. Int. J. Inv. Reprod. 9, 1-16.

Hadfield, M.G., Strathmann, M.F., 1996. Variability, flexibility and plasticity in life histories of marine invertebrates. Oceanol. Acta 19, 323-334.

Hamilton, W.D., 1967. Extraordinary sex ratios. Science 156, 477-488.

Hardege, J.D., Bartels-Hardege, H.D., 1995. Spawning behaviour and development of Perinereis nuntia var. brevicirrus (Annelida: Polychaeta). Invert. Biol. 114 (1), 39-45.

Havenhand, J.N., Todd, C.D., 1989. Reproductive effort of the nudibranch molluscs Adalaria proxima (Adler and Hancock) and Onchidoris muricata (Muller): an evaluation of techniques. Funct. Ecol. 3, 153-163. 
Hofmann, D.K., 1972. Nachweis der Epitokie als Fortpfanzunsmodus des Polychaeten Eunice siciliensis (Polychaeta: Annelida). Mar. Biol. 14, 341-344.

Hofmann, D.K., 1974. Maturation, epitoky and regeneration in the Polychaete Eunice siciliensis under field and laboratory condition. Mar. Biol. 25, 149-161.

Hofmann, D.K., 1975. Reproductive forms in eunicid polychaetes inhabiting the "fond coralligenes" in the region of Banyuls-s.-M. (Mediterranean Sea) with particular reference to Eunice siciliensis Grube. Pubb. Staz. Zool. Napoli. 39, 242-253.

La Greca, M., Bacci, G., 1962. Una nuova specie di Ophryotrocha delle coste tirreniche (Annelida, Polychaeta). Boll. Zool. 29, 13-24.

Lanfranco, M., Rolando, A., 1981. Sexual races and reproductive isolation in Ophryotrocha labronica la Greca and Bacci (Annelida Polychaeta). Boll. Zool. 48, 291-294.

Levin, L.A., 1984. Life-history and dispersal patterns in a dense infaunal polychaete assemblage: community structure and response to disturbance. Ecology 65, 1185-1200.

Malsen von, H., 1906. Geschlechtsbestimmende Einflusse und Eibildung des Dinophilus apatris. Arch. Mikrosc. Anat. Entw.-Mech. 69, 63.

Mettam, C., 1980. Survival strategies in estuarine nereids. In: Jones, N.V., Wolff, W.J. (Eds.), Feeding and Survival Strategies of Estuarine Organisms. Plenum Press, New York, NY, pp. 65-77.

Nishihira, M., Tsuchiya, M., Sato, M., 1984. Dispersal and recruitment of juveniles of the polychaete Lumbrinereis latreilli (Audouin et MilneEdwards). Bull. Mar. Biol. Stn. Asamushi Tohoku University 17, 191-203.

Olive, P.J.W., 1984. Environmental control of reproduction in Polychaeta. In: Fischer, A., Pfannenstiel, H.D. (Eds.), Polychaeta Reproduction. Fortschritte der Zoologi.e, vol. 29. Gustav Fischer Verlag, Stuttgart, NY, pp. 7-38.

Olive, P.J.W., Garwood, P.R., 1981. Gametogenic cycle and population structure of Nereis diversicolor and Nereis pelagica from Northeast England. J. Mar. Biol. Assoc. UK 61, 193-213.

Olive, P.J.W., Morgan, P.J., Wright, N.H., Zhang, S.L., 1984. Variable reproductive output in Polychaeta; options and design constraints. In: Engels, W., Clark Jr, W.H., Fischer, A., Olive, P.J.W., Went, D.F. (Eds.), Advan. Invertebr. Reprod., 3, pp. 399-408.

Olive, P.J.W., Porter, J.S., Sandeman, N.J., Wright, N.H., Bentley, M.G., 1997. Variable spawning success of Nephtys hombergi (Annelida: Polychaeta) in response to environmental variation: a life history homeostasis? J. Exp. Mar. Biol. Ecol 215, 247-268.

Prevedelli, D., 1989. Studio di una popolazione di Marphysa sanguinea (Montagu) (Polychaeta, Eunicidae) nella Laguna di Venezia: approccio autoecologico. Ph.D. Thesis. Università di Genova.

Prevedelli, D., Cassai, C., 2001. Reproduction and larval development of Perinereis rullieri Pilato in the Mediterranean Sea (Polychaeta: Nereididae). Ophelia 54, 133-142.

Prevedelli, D., Simonini, R., 2000. Effects of salinity and two food regimes on survival, fecundity and sex ratio in two groups of Dinophilus gyrociliatus (Polychaeta: Dinophilidae). Mar. Biol. 137, 23-29.
Prevedelli, D., Simonini, R., 2002. Relationship between body size and population growth rate in two opportunistic polychaetes. J. Mar. Biol. Ass. UK 82, 403-408.

Prevedelli, D., Zunarelli Vandini, R., 1999. Survival, fecundity and sex ratio of Dinophilus gyrociliatus (Polychaeta: Dinophilidae) under different dietary conditions. Mar. Biol. 132, 163-170.

Prevedelli, D., Castelli, A., Abbiati, M., Zunarelli Vandini, R., 1990. Distribution and life cycle of Perinereis rullieri Pilato (Polychaeta: Nereididae), a Mediterranean Endemism. Rapp. Comm. Int. Mer Médit. $32,1$.

Sato, M., Osanai, K., 1996. Role of jelly matrix of egg masses in fertilization of the polychaete Lumbrinereis latreilli. Inv. Reprod. Develop. 29, $185-191$.

Sato, M., Tsuchiya, M., Nishihira, M., 1982. Ecological aspect of the development of the polychaete, Lumbrinereis latreilli (Audouin et Milne-Edwards): signification of direct development and non simultaneous emergence of the young from the jelly mass. Bull. Mar. Biol. Stn. Asamushi Tohoku University 17, 71-85.

Schroeder, P.C., Hermans, C.O., 1975. Annelida: Polychaeta. In: Giese, A.G., Pearse, J.S. (Eds.), Reproduction of Marine Invertebrates, vol. 5. Academic Press, New York, NY, pp. 1-213.

Sella, G., Ramella, L., 1999. Sexual conflict and mating system in the dorvilleid genus Ophryotrocha and the dinophilid genus Dinophilus. Hydrobiologia 402, 203-213.

Sibly, R.M., Calow, R., 1989. A life-cycle theory of response to stress. Biol. J. Lin. Soc. 37, 101-116.

Simonini, R., 2002. Distribution and ecology of the genus Ophryotrocha (Polychaeta: Dorvilleidae) in Italian harbors and lagoons. Vie Milieu 52 (1), 59-65.

Smith, R.I., 1958. On reproductive patterns as a specific characteristics among nereid polychaetes. Syst. Zool. 7, 60-73.

Stearns, S.C., 1976. Life history tactics: a review of the ideas. Q. Rev. Biol. $51,3-47$.

Strathman, R.R., 1980. Why does a larva swim so long? Paleobiology 6, 373-376.

Strathman, R.R., 1982. Selection for retention or export of larvae in estuaries. In: Kennedy, V.S. (Ed.), Estuarine Comparisons. Academic Press, New York, NY, pp. 521-536.

Thorson, G., 1950. Reproductive and larval ecology of marine bottom invertebrate. Biol. Rev. 25, 1-45.

Traut, W., 1969. Zur Sexualität von Dinophilus gyrociliatus (Archiannelida). I. Der Einfluß von Außenbedingungen und genetischen Faktoren auf das Geschlechtsverhältnis. Biol. Zbl. 88, 469-495.

Tzonis, K., 1938. Beeinflussung der Geschlechtsverhältnisse bei Dinophilus apatris Korsch. durch Außenbedingungen. Zool. Jb. Physiol. 58, 539-550.

Vance, R.R., 1973. On reproductive strategies in marine benthic invertebrates. Am. Nat. 107, 339-352.

Westheide, W., 1984. The concept of reproduction in polychaetes with small body size: adaptation in interstitial species. Fortscr. Zool. 29, 265-287.

Wilson Jr, W.H., 1991. Sexual reproductive modes in polychaetes: classification and diversity. Bull. Mar. Sci. 48, 500-516. 